\title{
COMMENTARY
}

\section{Let's get dangerous - a review of current scholarship in public relation history}

Tom Watson PhD, Professor of Public Relations, The Media School, Bournemouth University \& Chair, International History of Public Relations Conference

\section{Introduction}

The motto of this commentary comes from the late Soviet president Nikita Khrushchev, who said in 1956: "Historians are dangerous and capable of upsetting everything”. It is applied in an ironic manner, as I wish that public relations historians were more challenging than they are. In this paper the "state of play" in the history of public relations field is considered. It reflects upon papers and keynote addresses delivered at the International History of Public Relations Conference (IHPRC), which was first held in 2010, and journal articles published since 2008. Using these data, recent historiography and scholarship are reviewed. The field, it will be shown, is trending from an initial eclectic, often descriptive, approach towards the more analytical and sometimes critical.

\section{Reconsideration}

I argue for reconsideration of the "Great Men” focus and the Anglo-American primacy (e.g. content of many texts and articles. In creating a history of public relations, some scholars and many introductory texts have relied too much on Thomas Carlyle's dictum that, "the history of the world is but the biography of great men”. It is greatly concerning that many developing country scholars apply Grunig \& Hunt’s four models (Grunig \& Hunt, 1984) and Excellence Theory as frames to record and benchmark the growth of their national PR sector using these convenient but culturally inappropriate standards.

There is, however, an emerging historiographic debate, exemplified by Meg Lamme and Karen Miller Russell's monograph - Removing the Spin: Towards a New Theory of Public Relations History (2010). Other important contributions are recent books, articles and presentations from Jacquie L’Etang, Günter Bentele, David McKie, Debashish Munshi, and Jordi Xifra. The 
impetus is growing for a genuine revision of the history of public relations in many countries which will show a less corporatist and more authentic foundation.

There is also a case for a distinction between public relations-like strategies and actions that occurred before publicity and public relations became discussed entities in the late $19^{\text {th }}$ century, which I call 'proto-PR', and 'public relations' itself. The exact time boundary may never be defined but publicity, press agentry and institutionalised communication activities were widely evident in some countries from around 1875 onwards.

\section{Status of the field}

The status of the public relations history field can be deduced from the more than 150 papers and keynotes presented at IHPRC from 2010 to 2013 and articles in public relations journals since 2008. The most frequent topics in papers have been event-based narratives, discussions on the formation of professional practice, and national histories. Most have been written in a descriptive or analytical style, with around $17 \%$ using critical methods. The picture that emerges is of PR historians telling stories and analysing them but not employing critical methods enough. The volume of papers and the analyses of type and style of article, however, indicate that PR history has moved beyond the “anorexic” stage described so vividly by McKie \& Munshi (2007, p. 118).

\section{Not a new field}

Although the history of public relations can be considered to be an emerging field, it is not new. In the 1960s, Ray Hiebert wrote Ivy Lee’s biography, Courtier to the Crowd (Hiebert, 1966). Each decade since, there has been a trickle of books but no increase in publication. Of course, many standard texts have a chapter on history but there wasn't a rising plane of publication until IHPRC started. The field thus has many articles and a few books which are mostly very readable narratives, some analysis, emerging interest from major publishers and new energy on the conference and journal article front. But where does PR history go to?

First, the other experiences and other voices of public relations, outside the Great Men and the western world must be researched. Much of the conventional history of public relations narrative is US-centric, in particular. Ivy Lee’s Declaration of Principles, Edward Bernays' self-promoted opinions and Arthur Page’s social science approaches have been lauded in general PR texts, 
biographies and by their own words. L'Etang (2008) acidly commented that “US scholars have always tended to assume that activities referred to as PR have been invented by Americans and exported elsewhere" (p.328). This is evidenced in Douglas Newsom's comment that: "Public relations is an occupation, some would say a profession, of uniquely US origin” (Newsom, 1984, p. 30). There are other voices and experiences of public relations in Europe and elsewhere that developed separately from the US model, as Nessman (2000) and Bentele (in many publications) have shown. In central Europe, there was a parallel but entirely separate development of public relations in that continent from 1848 onwards.

The evidence proves that it is possible to speak of an independent tradition of PR in Europe. In other words, the form of communication known as PR is not an American “invention” (Nessman, 2000, p.216).

\section{Other experiences}

We need to encourage PR historians, many of whom are new to the field, to move from reliance on the four Grunig models as the basis of analysis. Do they apply, for example, to Latvia, Thailand or Uganda when they have been developed from North American experience? These models are, to use a term that borrowed from journalism history, evidence of 'western hegemonic public relations'. My investigation into the formation of the International Public Relations Association (IPRA) in the 1950s and 1960s has found that western methods of public relations were considered as essential support for democracy through promotion of understanding between nations and as a barrier to Communism. However, unlike western journalism which suffered a backlash from the Non-Aligned Movement in the 1970s, the western hegemonic model of public relations moved serenely onwards and outwards as public relations was internationalised by multi-national corporations and US consultancy companies such as Burson-Marsteller (Leaf, 2012) and Hill \& Knowlton (Miller, 1999).

It was legitimised by some authors through application of the Grunig \& Hunt models. That may not have been the proponents' intention but it has been the outcome. L'Etang (2008) has argued that the Grunig typology is not appropriate for cultures with "different paths of historical evolution” (p. 319). By applying a framework from a Western corporatist culture to postCommunist Eastern Europe or communitarian south-east Asia, a dangerous short cut has been 
taken. More encouragement must be given to nascent historians to go to archives, gather interviews and data, and develop historical analyses.

\section{Proto-PR}

Another issue to consider is whether the history of public relations should be divided into two time periods. The main category would be the study of the organised communication practice and theory of what is widely recognised as 'public relations'. Taking into account the German/Austrian experience, discussed earlier, and that of the United States, this could start around 1875, some 140 years ago. In the US, there is evidence from Curtin (2008), Cutlip (1994, 1995), amongst others, and the recent Lamme \& Russell (2010) monograph, that utilities and railways were engaged in PR-like activities around this time. Before, there is much evidence of communication activity which had some characteristics of public relations. This has, however, often been deduced by post hoc analysis. There are numerous examples given which range from Sumerian walls displays, Greek rhetors, Roman emperors, early saints, crusades, and so on. I have contributed to this field through a study of the formation of a saintly cult in $10^{\text {th }}$ century Anglo-Saxon England (Watson 2008). These examples are not public relations, because they were not "seen as strategically planned activity in medieval times and ... did not use the framing of language and accumulated best practice that are applied now” (Watson 2008, p. 20). They were PR-like but were not PR.

For some time, I have proposed the use of the term, proto-PR or proto-public relations. It is based on "proto" meaning “original” or "primitive” (OED, 2005, p.601) and draws to mind the term “prototype” - “first or earlier form from which other forms are developed or copied” (ibid). The separation of proto-PR from PR itself will aid research and scholarship without diminishing interest in either category.

\section{Recent historiographic debate}

The debate over the historiography of public relations is increasingly fruitful. In addition to the McKie \& Munshi (2007) chapter and the L'Etang (2008) paper referred to earlier, there have been recent relevant papers or discussions on the writing of PR history, notably the Lamme \& Russell (2010) monograph and papers and IHPRC presentations by Bentele, and McKie \& Xifra. Lamme and Russell researched the historical perspective of public relations up to the end of the 
$19^{\text {th }}$ century. They argued against the progressive and upward phasing of PR's development and state that it did not conform to a "pattern of increasingly sophisticated or more ethical practices" (Lamme \& Russell, 2010, p. 354). This led them to a conclusion that "it is time to remove the spin from public relations history” and accept that the use of the progressive model of public relations’ inexorable development, as fostered by Bernays, Grunig and others, "was an attempt to clean up public relations’ image” (p.356).

In her keynote address to the first IHPRC in 2010, Karen Russell's theme was that PR historians must "embrace the embarrassing” if their research and writing is to be valid. Lamme and Russell's contribution to public relations historiography is that historians should be historians, not censors or promoters for public relations. The dominant model of managerialist corporate orientation of PR history set in a liberal democracy which exhibits improving ethical and practice standards is also no longer valid. Coombs \& Holladay (2012) made a similar point that the corporatist view of PR has been distorting and that by “alternatively grounding US public relations history in the work of activists, we open possibilities for re-imagining the field" (p.347). McKie \& Munshi (2007) argue that many of PR history’s accounts “are unique and unchallenged, or under-challenged, and in need of pluralising with robust perspectives” (p. 119) and "align with a modernist perspective" (p. 120).

\section{Conclusions - Let's get dangerous}

Future PR historiography should borrow from Khrushchev's 1956 statement and "get dangerous”. Much PR historical writing has been comfortable for too long: showing inexorable improvement and lauding great names. The field needs a more analytical stance and to move from the corporatist attitude that has dominated in order to research the messy, complex world of communication and persuasion. As well, a more critical view can be applied that involves "other voices” and considers the imbalances of power where PR has been applied to support dubious policies and propositions or to unbalance dialogues. Through an activist perspective, for example, historical research can show how NGOs, citizen groups and communities have used PR techniques to combat government and vested interests.

PR history that I really admire is research which pulls the professional veil aside and gathers data from new voices. An excellent example is the work of Dr Ian Somerville and colleagues at the 
University of Ulster who have undertaken "dangerous” research by investigating the development of PR strategies by the Irish Republican Army (IRA) and Protestant Loyalists during the Northern Ireland 'Troubles' from the 1970s to late 1990s (e.g. Somerville \& Purcell, 2011; Somerville \& Kirby, 2012). Some of those interviewed are now members of Northern Ireland's parliamentary assembly but others are still active in paramilitary organisations and thus "dangerous" people. An outcome of their research was that the IRA had a well-developed PR strategy (interviewees used the term) that competed with the British government through media relations and events. It was increasingly sophisticated though hardly symmetrical communication and definitely not corporatist. There's nothing comfortable in these studies of PR in action during a civil war, but it is cutting edge history with political and social dimensions. We shouldn't all put our heads in the lion's mouth in to research PR history, but we should increasingly investigate challenging governmental, corporate and NGO communication.

My final suggestion is that cooperation between PR historians must grow. We should map archives available to researchers. From them we can undertake comparative studies across nations, cultures and organisations. These, I believe, will get greater leverage for bids to research funding bodies and open up opportunities to seek industry funding which, other than in the US, is noticeable by its absence. In conclusion, there is a new energy in PR history research and scholarship. Let's continue to develop the field.

\section{References}

Coombs, W. T., \& Holladay, S. (2012). Privileging an activist vs. corporate view of public relations history in the US. Public Relations Review, 38(3), 347-353.

Curtin, P. A. (2008). Fred Harvey Company public relations and publicity (1876-1933). Journal of Communication Management, 12(4), 359-373.

Cutlip, S. M. (1994). The unseen power: Public relations, a history. Hillsdale, NJ: Lawrence Erlbaum Associates.

Grunig, J. E. \& Hunt, T. (1984). Managing public relations. New York, NY: Holt Rinehart \& Winston.

Hiebert, R. E. (1966). Courtier to the crowd: The story of Ivy Lee and the development of public relations. Ames, IA: Iowa State University Press. 
Lamme, M. O. and Miller, K. R., (2010). Removing the spin: towards a new theory of public relations history. Journalism \& Communication Monographs, 11(4).

Leaf, R. S. (2012). The Art of Perception. London: Atlantic Books

L'Etang, J. (2008). Writing PR history: Issues, methods and politics. Journal of Communication Management, 12(4), 319-335.

McKie, D., \& Munshi, D. (2007). Reconfiguring public relations. London: Routledge

Miller, K. (1999). The voice of business: Hill \& Knowlton and postwar public relations. Chapel Hill, NC: The University of North Carolina Press.

Nessman, K. (2000). The origins and development of public relations in Germany and Austria. In: Moss, D., Vercic, D., \& Warnaby, G., (Eds), Perspectives on public relations research. London: Routledge, pp. 211-225.

Newsom, D. (1984). Public relations and the question of provinciality. IPRA Review, 8(3), 30-31

OED, (2006). Paperback Oxford English dictionary. Oxford: Oxford University Press.

Somerville, I., \& Purcell, A. (2011). A history of Republican public relations in Northern Ireland from "Bloody Sunday" to the "Good Friday Agreement”. Journal of Communication Management, 15(3), 192-209.

Somerville, I., \& Kirby, S. (2012). Public relations and the Northern Ireland peace process: Dissemination, reconciliation and the 'Good Friday Agreement' referendum campaign. Public Relations Inquiry, 1(3), 231-255.

Watson, T. (2008). Creating the cult of a saint: Communication strategies in 10th century England. Public Relations Review, 34(1), 19-24. 